\title{
Subvalvular aortic stenosis (subaortic stenosis): a case series
}

\section{Alma Sijamija ${ }^{1 *}$, \\ CNermir Granov ${ }^{2}$, \\ Domer Perva2 ${ }^{2}$, \\ - Lejla Granov \\ Aladjuz', \\ - BBerka Begović ${ }^{3}$, \\ CNedžad Hadžićc}

'Travnik General Hospital,

Travnik, Bosnia and

Herzegovina

${ }^{2}$ Clinical Center University of Sarajevo, Sarajevo, Bosnia and Herzegovina

${ }^{3}$ Bugojno General Hospital, Bugojno, Bosnia and Herzegovina

\begin{abstract}
KEYWORDS: subvalvular aortic stenosis, subaortic membrane, septal myectomy. CITATION: Cardiol Croat. 2019;14(3-4):80-1. | https://doi.org/10.15836/ccar2019.80
\end{abstract}

*ADDRESS FOR CORRESPONDENCE: Alma Sijamija, J.U. Bolnica Travnik, Kalibunar bb, 72270 Travnik, Bosna and Herzegovina. / Phone: +387-61-780-085 / E-mail: alma.sijamija@hotmail.com

ORCID:Alma Sijamija, https://orcid.org/0000-0003-2818-0501 • Nermir Granov, https://orcid.org/0000-0002-6228-6230 Omer Perva, https://orcid.org/0000-0003-2645-1558 • Lejla Granov Aladjuz, https://orcid.org/0000-0003-4737-0183 Berka Begović, https://orcid.org/0000-0003-3746-395X • Nedžad Hadžić, https://orcid.org/0000-0002-7186-7803

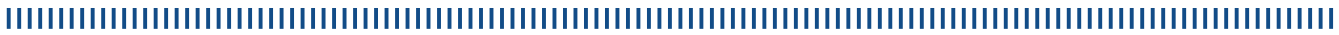

Introduction: Subvalvular aortic stenosis, which may have a dynamic component, may be due to a fibrous membrane, muscular obstruction, or a combination of the $2^{1,2}$. About $50 \%$ of patients with a subaortic membrane also have leakage of the aortic valve. Left ventricular outflow tract (LVOT) obstructive lesions account for approximately 6 percent of cases of congenital heart disease in children; the incidence was estimated to be 6 in 10,000 live births ${ }^{3,4}$. Subvalvar aortic stenosis (AS) is the second most common form of AS. Among children with congenital AS, subvalvar AS accounts for 10 to 14 percent of cases ${ }^{4}$. Subvalvar AS is more common in males, who account for 67 to 75 percent of cases $^{4}$. Patients with severe or untreated subaortic stenosis may be at risk for sudden cardiac death. An echocardiogram will show the level and severity of the obstruction. It will also show if the left ventricle is thickened or enlarged. The progression is often very slow. This is especially true in people whose obstructions are not detected until they are adults. Surgery may be necessary to stop the progression of subaortic stenosis
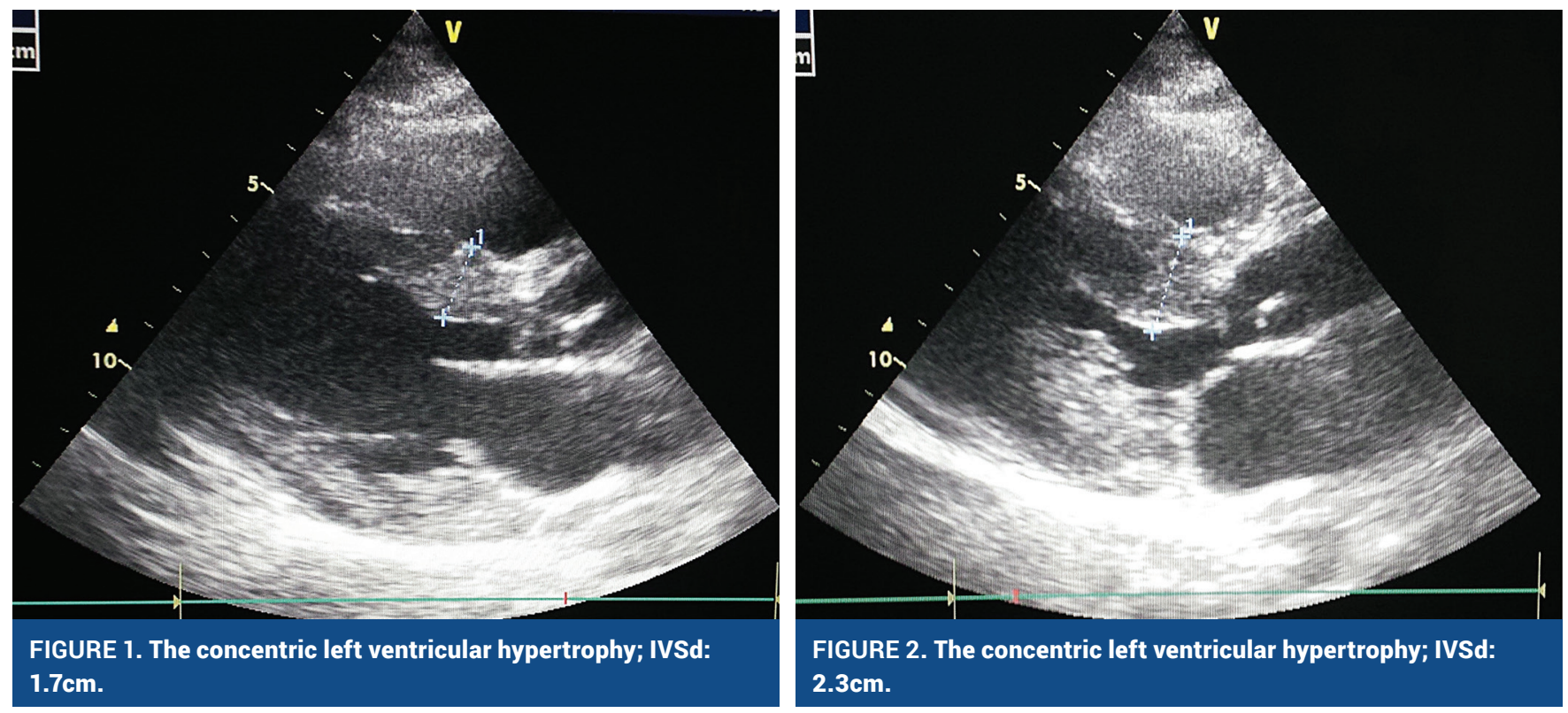

RECEIVED:

February 28, 2019

ACCEPTED:

March 24, 2019

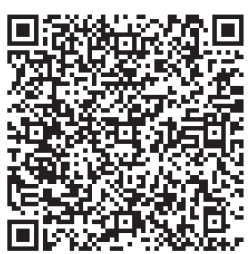

$\square$ Cardiologia Croatica 2019;14(3-4):80.
Case 1: 25-year-old female patient was admitted on our department, resuscitated and afterward intubated due to ventricular fibrillation. Her condition was additionally complicated by allergy reaction and signs of acute respiratory distress syndrome. In the age of 6 verified CHA. TTE show hypertrophic obstructive cardiomyopathy (HOCM) with PGmean $76 \mathrm{mmHg}$ and PGmax $142 \mathrm{mmHg}$ in LVOT. Two months later she underwent surgical operation of septal myectomy. 10 years later she is healthy and gave two births.

Case 2. 36-years-old female patient, growth with developmental difficulties, adipose with amaurose. Within the preoperative preparation for cholecystectomy operation was diagnosed for HOCM (Figure 1, Figure 2), subvalvular subaortic membrane (Figure 3), with high gradients of subaortic stenosis, PG 
mean 54mmHg in the LVOT and mild aortic valve regurgitation (Figures 4-6). After cholecystectomy operation, she was scheduled for surgical correction of HOCM

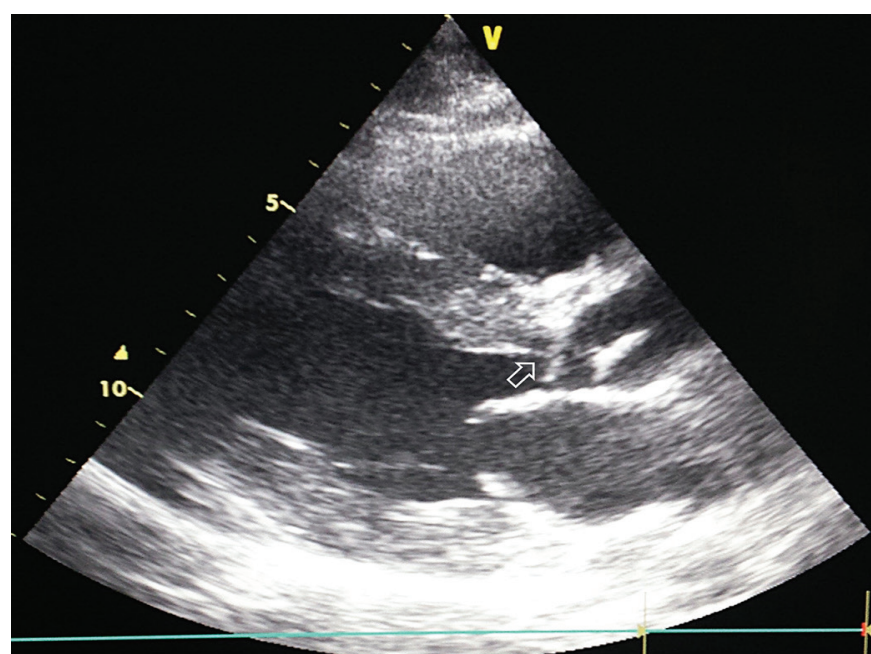

FIGURE 3. The presence of a subaortic membrane (small white arrow).

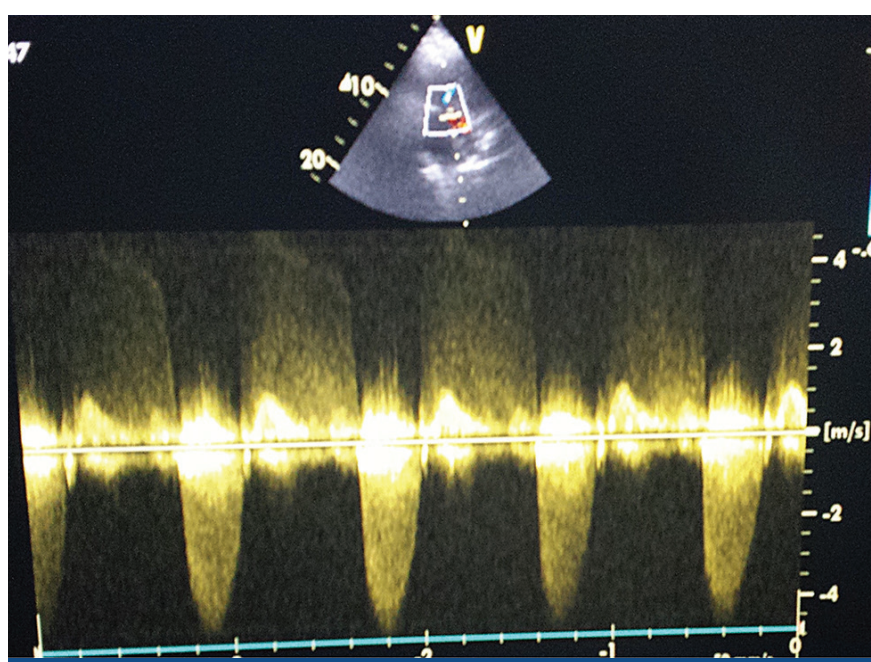

FIGURE 4. A subaortic membrane with severe stenosis gradient, moderate aortic regurgitation.

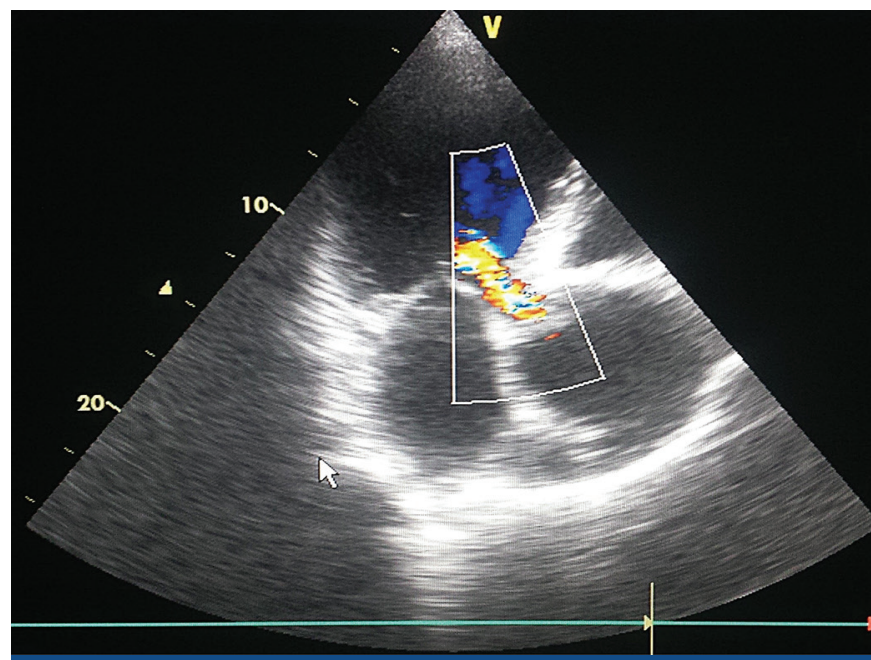

FIGURE 5. The presence of aortic regurgitation.

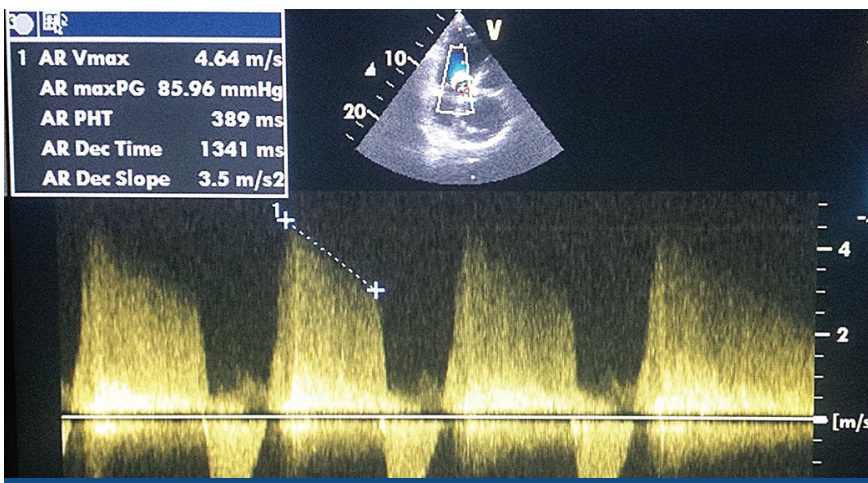

FIGURE 6. Quantification of aortic regurgitation using continuous wave Doppler.

Conclusion: Although the development of left ventricular hypertrophy or aortic regurgitation is a clear indication for operation, the timing of intervention in the otherwise asymptomatic patient remains a point of controversy.

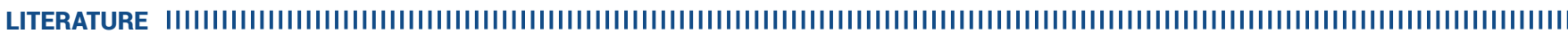

1. Aboulhosn J, Child JS. Left ventricular outflow obstruction: subaortic stenosis, bicuspid aortic valve, supravalvar aortic stenosis, and coarctation of the aorta. Circulation. 2006 Nov 28;114(22):2412-22. https://doi.org/10.1161/CIRCULATIONAHA.105.592089

2. Maron BJ, Gottdiener JS, Arce J, Rosing DR, Wesley YE, Epstein SE. Dynamic subaortic obstruction in hypertrophic cardiomyopathy: analysis by pulsed Doppler echocardiography. J Am Coll Cardiol. 1985 Jul;6(1):-1-18. https://doi.org/10.1016/S0735-1097(85)80244-8

3. Hoffman JI, Christianson R. Congenital heart disease in a cohort of 19,502 births with long-term follow-up. Am J Cardiol. 1978 0ct;42(4):641-7. https://doi.org/10.1016/0002-9149(78)90635-5

4. Kitchiner D, Jackson M, Malaiya N, Walsh K, Peart I, Arnold R. Incidence and prognosis of obstruction of the left ventricular outflow tract in Liverpool (1960-91): a study of 313 patients. Br Heart J. 1994 Jun; $71(6): 588-95$. PubMed: https://www.ncbi.nlm.nih.gov/pubmed/8043345 